\title{
Non-Performing Loans: A Catastrophic Phenomena in Banking Sector of Bangladesh
}

\author{
Md Sayeed Al Mamun Anik ${ }^{1 *}$, Rumana Rahman Bristy ${ }^{1}$, Shamim Alam, \\ Laazina Khan Hrisha ${ }^{1}$, Nazmul Hasan ${ }^{1}$ \\ 1. Dhaka School of Bank Management (affiliated with University of Dhaka), Bangladesh Institute of Bank \\ Management (BIBM), Section 02 Mirpur, Dhaka-1216, Bangladesh. \\ * E-mail of the corresponding author: sayeedalmamunanik@gmail.com
}

\begin{abstract}
Nonperforming loan (NPL) is one of the most cataclysmic phenomena for the entire banking industry in Bangladesh. NPLs in the banking sector have experienced a monstrous escalation of $300 \%$ in the last decade and statistically this figure is more than 1000 billion of Bangladeshi Taka (BDT). Even though international standards of loan classification and provisioning system is being adopted, the management of NPL is found unproductive. Fundamentally, deficiency of good governance, weak supervision, corruption, political interference in approving loans, culture of impunity and professional ineptness of bankers to deal with the pressing issue have played an instrumental role for the swift upsurge of NPLs. Pertaining to preventive measures, prominence needs to be placed on credit screening, loan surveillance, stringent law enforcement, centralized loan authorization system, strong monetary policy and strong loan review functionaries. Therefore, this study has emphasized on the challenges of NPL, evocative ways for improving the debt recovery environment and cracking the NPL problems in order to safeguard a sustainable banking sector of the country.
\end{abstract}

Keywords: non-performing loan, loan classifications, provisioning, good governance, sustainable banking

DOI: $10.7176 / \mathrm{EJBM} / 12-27-14$

Publication date:September $30^{\text {th }} 2020$

\section{Introduction}

Bangladesh depends profoundly on the banking industry for smooth financial intermediation. There is also an underdeveloped capital market that primarily hinge on the transitional role of commercial banks for mobilizing internal saving and providing capital to the investors. Banks thus contribute to the development of the economy through effective and efficient lending. However, bank operates its business through deposit collection from the surplus economic unit and provides this loan to the deficit economic unit that requires loan.

A Non-performing loan is defined as a loan that is in default or close to being in default. IMF defines NPLs as: "A loan is nonperforming when payments of interest and principal are past due by 90 days or more, or at least 90 days of interest payments have been capitalized, refinanced or delayed by agreement, or payments are less than 90 days overdue". As per Section 5 (cc) of Bank Company Act 1991: 'defaulting debtor' means any person or institution served with advance, loan granted in favour of him or an institution involving interest or any portion thereof, or any interest which has been overdue for six months in accordance with the definition of Central Bank of Bangladesh.

NPA (non-performing asset) in the banking sector may be termed as an asset not causative to the income of the bank or it is a zero-yield asset when applied particularly to loan and advances. Our banking sector currently facing the critical problem of NPL as a sign of ineffective lending practices and day by day the problem increases although many reform measures have been carried out. The increasing amount of NPL threatens the financial performance of the banks especially the State-owned Commercial Banks (SCBs). In SCBs the impact of NPL is in a distressing status quo. It is palpable that NPLs diminish banks' profitability, as banks cannot appropriate interest revenue from their classified loans. NPLs reduce loan able funds by discontinuing recycling forcing banks to set aside a portion of their income as loan loss reserve (Provision) to make up bad debt. A bank with a high ratio of NPLs vacillates from erosion of the capital if there is no provision. Combination of these adverse impressions of NPLs destruct banks' financial health such as low profitability and low capital base which are evidently reflected in Bangladesh banking sector.

\section{Loan Classification System}

From 1989, Bangladesh incorporated both "Overdue Criteria" and "Qualitative Criteria" to consider a loan 
classified or unclassified. Consistent with overdue criteria, bank managers typically split all loans into five classes such as: Continuous loan, Demand loan, Term loan payable within five years, Term loan payable in more than five years and Short-term agricultural credit or micro credit. They then observe the dates for repayments which have expired. To comply with international standards of loan classification, all distressed loans are then further reclassified as Special Mention Account (SMA), Substandard (SS), Questionable and Bad / Losses. In addition, bank managers monitor the loan quality on a quarterly basis in order to keep the management up to date on the status of loans. With some exemptions, the banking sector presently follows a practice of six months overdue for deeming a loan as nonperforming. The rate of provision on classified loans follows norms of 5\%, 20\%, 50\% and $100 \%$ against special mention accounts, substandard, doubtful, and bad/loss loans respectively.

Special Mention: $5 \%$
Doubtful: $50 \%$

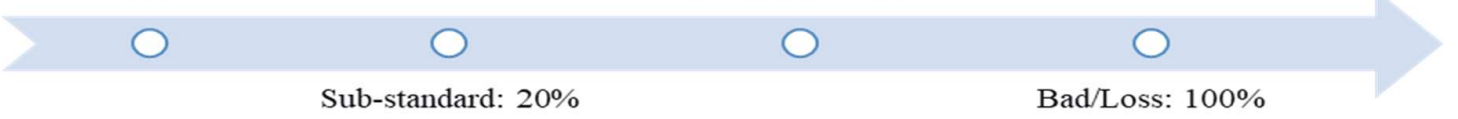

Figure 1. General Provision against Loans

Table 1. Loan Classification System

\begin{tabular}{|c|c|c|c|}
\hline Period overdue & $\begin{array}{c}\text { Status of } \\
\text { classification }\end{array}$ & Rate of provision & $\begin{array}{c}\text { Frequency of } \\
\text { classification }\end{array}$ \\
\hline$<3$ months & Unclassified & $1 \%-5 \%$ & \\
\hline $\begin{array}{c}\text { Loans overdue for } 3 \\
\text { months but less than } 6 \\
\text { months }\end{array}$ & Substandard & $10 \%-25 \%$ & $\begin{array}{c}\text { At least quarterly, } \\
\text { usually monthly. }\end{array}$ \\
\hline $\begin{array}{c}\text { Loans overdue for } 6 \\
\text { months but less than } 9 \\
\text { months }\end{array}$ & Doubtful & $50 \%-75 \%$ & \\
\hline m months & Bad/loss & $100 \%$ & \\
\hline
\end{tabular}

Source: Studies in Bangladesh Banking: Series 1, Page 67.

\subsection{Loan Classification in Bangladesh}

a) Continuous loan: The loan that is authorized without specific repayment schedule but there is a specific expiry date for refund and credit limit can be treated as continuous loan. For examples: Cash Credit (CC), Packing Credit (PC), Loan against Imported Merchandise (LIM), Loan against Trusted Receipt (LTR) etc.

b) Demand Loan: When loan is sanctioned on the basis of repayment that hinge on the demand of bank can be called as demand loan. Alternatively, when contingent or other liabilities are transformed into forced loan are also to be treated as demand loan. For examples: Forced LIM, Payment Against Documents (PAD), Foreign Bill Purchase (FBP) etc.

c) Term Loan: The loan which has a specific expiry date for repayment and for which repayment is schedule through specific repayment schedule is treated as fixed term loan. For example: Project finance, industrial finance etc.

d) Short-Term Agricultural Credit and Micro-Credit: Short-Term Agricultural Credit means the credit which is enlisted as short-term credit under the annual credit program announced by Agricultural Credit Department of Central bank of Bangladesh. Credit in agriculture sector repayable within 12 months is also included in this category. On the other hand, Short- Term Micro-Credit means the credit which have loan limit less than TK. 
25000.00 and repayable within 12 months. Micro-credit may be even non-farm credit, self-employment credit, loom-loan or any forms of credit under the own credit program of the banks.

\subsection{Basis for Loan Classification}

For emergence of any uncertainty or doubt in respect of recovery of any Continuous Loan, Demand Loan or Fixed Term Loan, the same needs to be classified on the basis of qualitative judgement. If there occurs any situational change in the stipulations in terms of which the loan was extended or if the capital of the borrower is weakened due to antithetical conditions or if the value of the collateral decreases or if the recovery of the loan becomes uncertain due to any other unfavourable situation, the loan will have to be classified on the basis of qualitative judgement. Despite the probability of any loan being affected due to the reasons stated above or for any other reasons, if there is any hope for change of the existing condition by resorting to proper steps, the loan, on the basis of qualitative judgement, will be classified as 'Sub-standard '. But even after resorting to proper steps, there exists no certainty of total recovery of the loan, it will be classified as ' Doubtful ' and even after exerting the all-out efforts, there exists no chance of recovery, it will be classified as ' Bad/Loss ' on the basis of qualitative judgement.

\section{NPL in Banking Sector of Bangladesh}

Default loan is the most concerning issue in the country's banking sector. It has reached to a new heights as total default loans have crossed BDT 100,000 crore for the first time in the country's 49-year history. Weak supervision, influence of political agenda and bad governance played an instrumental role for skyrocketing of toxic loans. Besides, the culture of impunity, political interference in approving loans and neglecting the due diligence (KYC, KYCC) have aggravated the already battered banking industry.

\subsection{Extent of the NPL}

Banks are financial intermediaries that mobilize funds from surplus economic units and allocate those funds to deficit economic units. Bank mobilizes fund mainly through collecting deposits and allocate those funds by providing loans. Bank credit is the principal sources of loanable fund for millions of households and the government. Agricultural, commercial, and industrial activities of a nation are often financed by bank credit. Without adequate financing there can be no growth or maintenance of stable output. Thus, the bank credit influences total macroeconomic environment by affecting money supply, investment, total output, and employment. This process is an ongoing one that begins when a loan application is made and screened (origination) and continues until the loan is repaid. As unpaid loans are incomplete transactions for lenders this incomplete transaction will not add any value rather destroy it. And this unpaid or default loan causes constraints on the process of economic development.

\subsection{Emergence of $N P L$}

As banking remains the main intermediary vehicle of harnessing investible capital for accelerating the growth of the productive sectors in Bangladesh, the continuing crisis of accumulation of non-performing and defaulted bank loans has emerged as one of the most serious constraints in the path of economic development of our country.

\subsection{Trend of the Loan Default Problem in Bangladesh}

The ratio of gross non-performing loans (NPLs) to total loans and net NPLs to net total loans is the most important metric for demonstrating the asset quality in the loan portfolio. At the end of June 2019, the gross NPL of the banking sector stood at 11.7\%. Table 2 also shows that Foreign Commercial Banks (FCBs) had the lowest and State-owned Commercial Banks (SCBs) had the highest gross NPLs during this period. PCBs' gross NPLs was $7.1 \%$, whereas those of SCBs, Foreign Commercial Banks (FCBs) and Development Financial Institutions (DFIs) were 31.6, 5.5 and 17.8 percent respectively at the end of June 2019. 
Table 2. Gross NPLs to Total Loans by Types of Banks (In Percent)

\begin{tabular}{lllllllllll}
\hline $\begin{array}{l}\text { Bank } \\
\text { Types }\end{array}$ & $\mathbf{2 0 1 0}$ & $\mathbf{2 0 1 1}$ & $\mathbf{2 0 1 2}$ & $\mathbf{2 0 1 3}$ & $\mathbf{2 0 1 4}$ & $\mathbf{2 0 1 5}$ & $\mathbf{2 0 1 6}$ & $\mathbf{2 0 1 7}$ & $\mathbf{2 0 1 8}$ & $\begin{array}{l}\mathbf{2 0 1 9} \\
\text { (June) }\end{array}$ \\
\hline SCBs & 15.7 & 11.3 & 23.9 & 19.8 & 22.23 & 21.5 & 25.1 & 26.5 & 30.0 & 31.6 \\
\hline DFIs & 24.2 & 24.6 & 26.8 & 26.8 & 32.81 & 23.2 & 26.0 & 23.4 & 19.5 & 17.8 \\
\hline PCBs & 3.2 & 2.9 & 4.6 & 4.5 & 4.98 & 4.90 & 4.60 & 4.90 & 5.5 & 7.1 \\
\hline FCBs & 3.0 & 3.0 & 3.5 & 5.5 & 7.30 & 7.80 & 9.60 & 7.04 & 6.5 & 5.5 \\
\hline Total & 7.3 & 6.1 & 10.0 & 8.9 & 9.7 & 8.8 & 9.2 & 9.3 & 10.3 & 11.7 \\
\hline
\end{tabular}

Source: Annual Report 2018-19, Central Bank of Bangladesh

The ratio of gross NPLs to total loans indicates a fluctuating trend in the banking system. during 2010-2019. It declined in 2011 and increased in 2012 (10.0 percent) and again declined in 2013 (8.9 percent). Afterward, the ratio jumped in 2014 (9.7 percent) and again declined in 2015 ( 8.8 percent). But the ratio shows an upward trend in recent years mainly due to increase in total classified loans, defaulted outstanding and non-recovery of loans. At the end of June 2019, it stood at $11.7 \%$ (Figure 2).

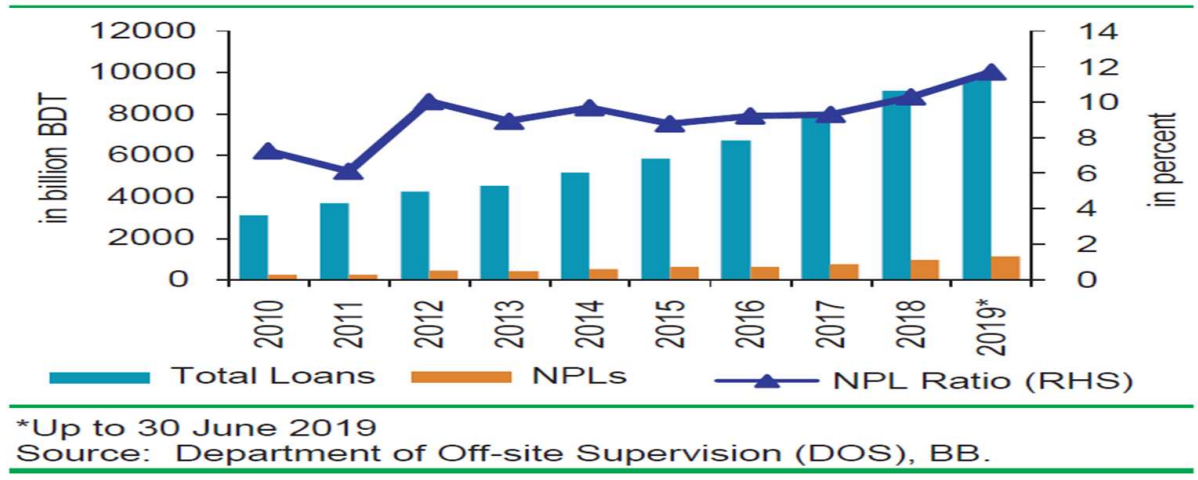

Figure 2. Aggregate Position of NPLs to Total Loans

Figure-3 below shows the amount of NPLs of the four types of banks since 2010 to 2019. During this period, the amount of NPLs of SCBs, DFIs, PCBs and FCBs have increased by BDT 369.5 billion, BDT 5.8 billion, BDT 319.7 billion and BDT 19.4 billion respectively. As of June 2019, the NPL of the banking sector was BDT 1124.2 billion.

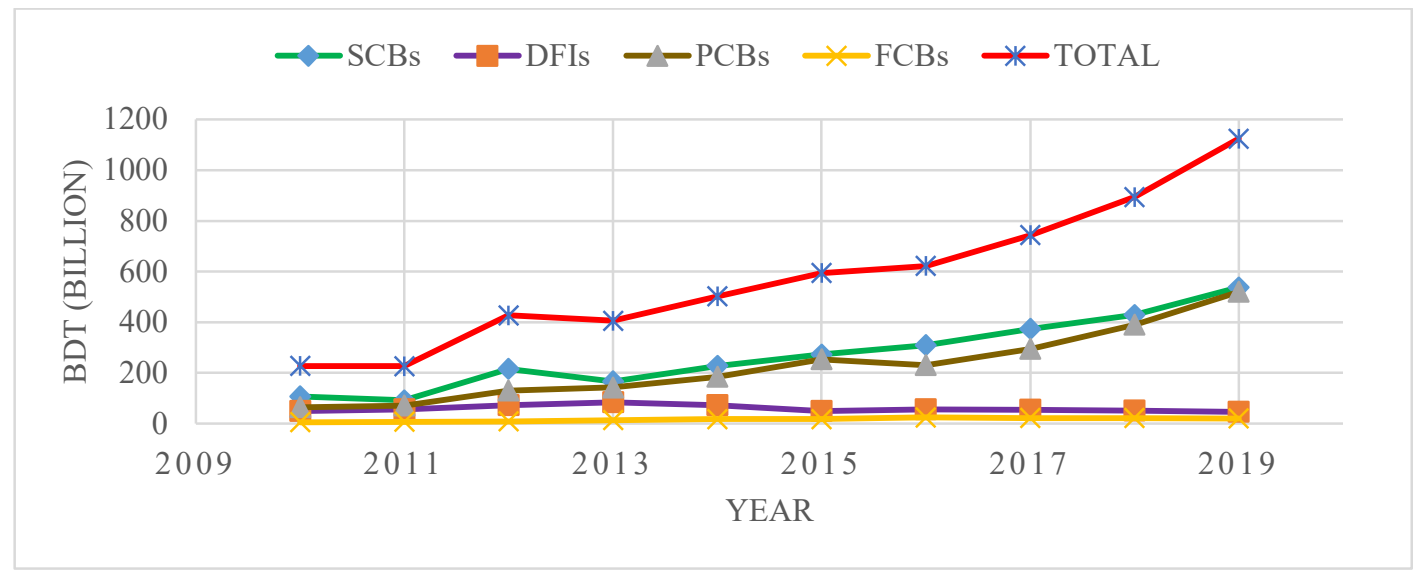

Figure 3. Amount of NPLs by types of banks 
The amount of NPLs have increased in SCBs and PCBs whereas NPLs have decreased in DFIs and FCBs in recent years. The amount of NPLs of SCBs, DFIs, PCBs and FCBs Stood at BDT 537.4, 47.0, 519.2 and 20.6 billion respectively at the end of June 2019.

Table 3. Required Provision and Provision Maintained by the Banking Industry (In billion BDT)

\begin{tabular}{lcccccccccc}
\hline All Banks & $\mathbf{2 0 1 0}$ & $\mathbf{2 0 1 1}$ & $\mathbf{2 0 1 2}$ & $\mathbf{2 0 1 3}$ & $\mathbf{2 0 1 4}$ & $\mathbf{2 0 1 5}$ & $\mathbf{2 0 1 6}$ & $\mathbf{2 0 1 7}$ & $\mathbf{2 0 1 8}$ & $\begin{array}{l}\mathbf{2 0 1 9} \\
\text { (June) }\end{array}$ \\
\hline $\begin{array}{l}\text { Amount } \\
\text { of NPLs }\end{array}$ & 227.1 & 226.4 & 427.3 & 405.8 & 501.6 & 594.1 & 621.7 & 743.0 & 939.1 & 1124.2 \\
\hline $\begin{array}{l}\text { Required } \\
\text { Provision }\end{array}$ & 149.2 & 148.2 & 242.4 & 252.4 & 289.6 & 308.9 & 362.1 & 443.0 & 570.4 & 712.4 \\
\hline $\begin{array}{l}\text { Provision } \\
\text { Maintained }\end{array}$ & 142.3 & 152.7 & 189.8 & 249.8 & 281.6 & 266.1 & 307.4 & 375.3 & 504.3 & 620.2 \\
\hline $\begin{array}{l}\text { Excess (+) } \\
\text { Shortfall (-) }\end{array}$ & -6.9 & 4.6 & -52.6 & -2.6 & -7.9 & -42.8 & -54.7 & -67.7 & -66.1 & -92.2 \\
\hline $\begin{array}{l}\text { Provision } \\
\text { Maintenance } \\
\text { Ratio (\%) }\end{array}$ & 95.4 & 103.0 & 78.3 & 99.0 & 97.2 & 86.1 & 84.9 & 84.7 & 88.4 & 87.10 \\
\hline
\end{tabular}

Source: Annual Report 2018-19, Central Bank of Bangladesh

Table 3 shows the aggregate amount of NPLs, the required loan loss provision and the actual provision maintained by the banks from 2010 to 2019 . It shows that except for the year 2011, there were provision shortfall against NPLs in the banking sector. The ratio showed declining trend from 2014 to 2017 and in 2018 the situation was slightly improved with the ratio stood at 88.4 percent. As of June 2019, provision maintenance ratio of the banking industry was 87.10 percent.

The main reason for the shortfall in provision was the inability of some SCBs and PCBs, including those in the problem bank category due to increase in classified loans, poor quality and inadequacy of collaterals, low profit and provision transfer for write-offs. On the other hand, the FCBs were in a much better position since they were able to keep adequate provisions. A comparative position of loan loss provisions of four types of banks as of 20162019 is shown in Table 4.

As loans comprise the most important asset as well as the primary source of earning for the banking financial institutions and on the other hand also the major source of risk for the bank management so a prudent bank management should always try to make an appropriate balance between its return and risk involved with the loan portfolio. But Banking sectors recent involving activities, guidelines and their concentration in that is not satisfactory.

The prudential guidelines also call for making adequate "provisions" against classified loans in order to protect the financial health of the banks are prepared but which is worthless as by making provision the number of willful defaulters are increasing day by day. The economic implications of the default loans are not only stoppage of creating new loans but also the erosion of banks profitability, liquidity and solvency, which might sometimes lead towards collapse of the banking financial system. It has, therefore, become sine qua-non for policy makers to study the loan default scenario of the banking sector of a routine basis for estimating classified loan, making appropriate provisioning, adopting effective recovery strategy and thus ensuring soundness and efficiency of the banking sector. 
Table 4. Comparative Position of Provision Adequacy by Types of Banks (In billion BDT)

\begin{tabular}{|c|c|c|c|c|c|}
\hline Year & Items & SCBs & DFIs & PCBs & FCBs \\
\hline \multirow{3}{*}{2016} & $\begin{array}{l}\text { Required } \\
\text { Provision }\end{array}$ & 174.0 & 27.8 & 144.2 & 16.0 \\
\hline & $\begin{array}{l}\text { Provision } \\
\text { Maintained }\end{array}$ & 113.2 & 28.4 & 149.4 & 16.4 \\
\hline & $\begin{array}{c}\text { Provision } \\
\text { Maintenance } \\
\text { Ratio (\%) }\end{array}$ & 65.1 & 102.2 & 103.6 & 102.5 \\
\hline \multirow{3}{*}{2017} & $\begin{array}{l}\text { Required } \\
\text { Provision }\end{array}$ & 216.9 & 26.1 & 184.3 & 15.6 \\
\hline & $\begin{array}{l}\text { Provision } \\
\text { Maintained }\end{array}$ & 134.3 & 26.2 & 198.2 & 16.5 \\
\hline & $\begin{array}{c}\text { Provision } \\
\text { Maintenance } \\
\text { Ratio }(\%)\end{array}$ & 61.9 & 100.4 & 107.5 & 105.8 \\
\hline \multirow{3}{*}{2018} & $\begin{array}{l}\text { Required } \\
\text { Provision }\end{array}$ & 252.9 & 25.0 & 234.6 & 16.2 \\
\hline & $\begin{array}{l}\text { Provision } \\
\text { Maintained }\end{array}$ & 162.0 & 27.9 & 242.0 & 16.9 \\
\hline & $\begin{array}{c}\text { Provision } \\
\text { Maintenance } \\
\text { Ratio (\%) }\end{array}$ & 64.1 & 111.6 & 103.2 & 104.3 \\
\hline \multirow{3}{*}{ June 2019} & $\begin{array}{l}\text { Required } \\
\text { Provision }\end{array}$ & 353.0 & 22.3 & 321.2 & 15.8 \\
\hline & $\begin{array}{l}\text { Provision } \\
\text { Maintained }\end{array}$ & 284.5 & 25.4 & 293.1 & 17.3 \\
\hline & $\begin{array}{c}\text { Provision } \\
\text { Maintenance } \\
\text { Ratio }(\%)\end{array}$ & 80.6 & 113.9 & 91.3 & 109.5 \\
\hline
\end{tabular}

Source: Annual Report 2018-19, Central Bank of Bangladesh

\section{Causes \& Effects of NPL}

Basically, the lack of good governance, corruption, political interference in approving loans and culture of impunity are to be blamed for the endless journey of NPLs in the sector.

\subsection{Causes of the NPL}

The causes of non-performing loan are explained elaborately in the following:

Unwillingness to pay is one of the most common reasons behind default culture in Bangladesh. It can happen in some situations like when security-backing loan is weak; customer feels that defaulting the loan will not harm them much. In that case they tend to default. In other instances, when cash flow from the corporation is not impressive, individuals are hesitant to repay the loans.

Businesses often need funding from other sources, such as government authorities. Without timely feeding, a company in consecutive time periods, may become sick and incur losses. In our country most of the companies do not have the supporting sources with which they can withstand the turmoil that comes in to their business from time to time.

The non-attractive sector also serves as the primary cause of default on loans. Firms working in non-attractive sectors are more likely to perform poorly. Because of poor financial performance, company's cash flow gets 
affected. The business becomes less liquid due to cash flow, which leads to the default of bank loans. In addition, state-owned banks provide loans for the growth of specialized sectors such as jute, leather and agriculture, but often they are unable to repay and banks do not take stern action to recover in view of the sensitivities.

Banks look at the issue of how the business is run before sanctioning a loan. If the bank assumes that the management is competent enough to operate the organization efficiently and use bank financing, then the bank decides not to financing otherwise. Even sometimes banks set conditions like some of the key personnel must not quit the organization before repayment of the loan. Managerial capability plays vital role in repaying bank loan.

Mainly default loans occur due to weak cash flow of enterprises. Company becomes chaotic and illiquid due to erratic cash flow. In that case, company does not have ample cash to pay and interest for service loans. Even if a business is profitable, because of cash flow, the business can default. A company may sell most of its finished products on credit in some cases. This shortfall could trigger a default.

Low market share means low revenue, low revenue means low profit, and low profit causes default. Operating in a niche market, a company may be profitable enough to repay its entire loan obligation and maintain sizeable profits with a very low market share. But it will not be profitable if it operates in a niche product in a market that is not desirable or has less clients than it anticipated. So, it cannot pay its interest payment.

Banks often postpone the assessment of credit proposals by business firms. Because of the delayed appraisal by the bank, when the business desperately needs capital, it does not get enough funds. In their business activities, this creates a lack of cash. They barely handle their everyday business costs, let alone the repayment of loans. The bankers often approve loans of big amounts without taking into consideration the collateral. In many cases, banks provide loans to bank defaulters bypassing the BB's directions. Thus, banks are largely responsible for the rise in default loans in this case.

Via monitoring, lenders become aware of whether or not their funds are being used for the intended reason. Sometimes disbursed money is used for purposes other than the specific areas. Therefore, risk of loan default gets higher. Banks sanction loan on the basis of feasibility of the project. As a lender, the bank expects the loan to be serviced by the cash flow created from that specific sector. But if credit is used in some other areas desired cash flow may not come from the business and chance of loan default gets high. Most banks in our country don't monitor activities of the borrower whether the fund is being properly utilized or business is generating enough cash flow or not as well as don't use specialized formats for loan monitoring. In many banks, the security or collateral valuation culture is missing. It is the prime duty of the banks to justify the eligibility of a company in getting loans as well as its capacity to repay. But this is absent in approving loans as the bankers are sometimes involved in the corruption and give loans resorting to irregularities.

\subsection{Effects of the NPL}

The recent rising trends of NPL in the overall banking system in Bangladesh are major concerned for policymakers and the stakeholders, because high NPLs give huge stress in the banks to earn profit and weaken the financial stability. Figure 4 show the trends of NPLs and two key profitability indicators; the Returns on Assets (ROA) and Returns of Equity (ROE) during the 2014-2018. It is detected from the figure that there is a negative relationship among NPL, ROA and ROE.

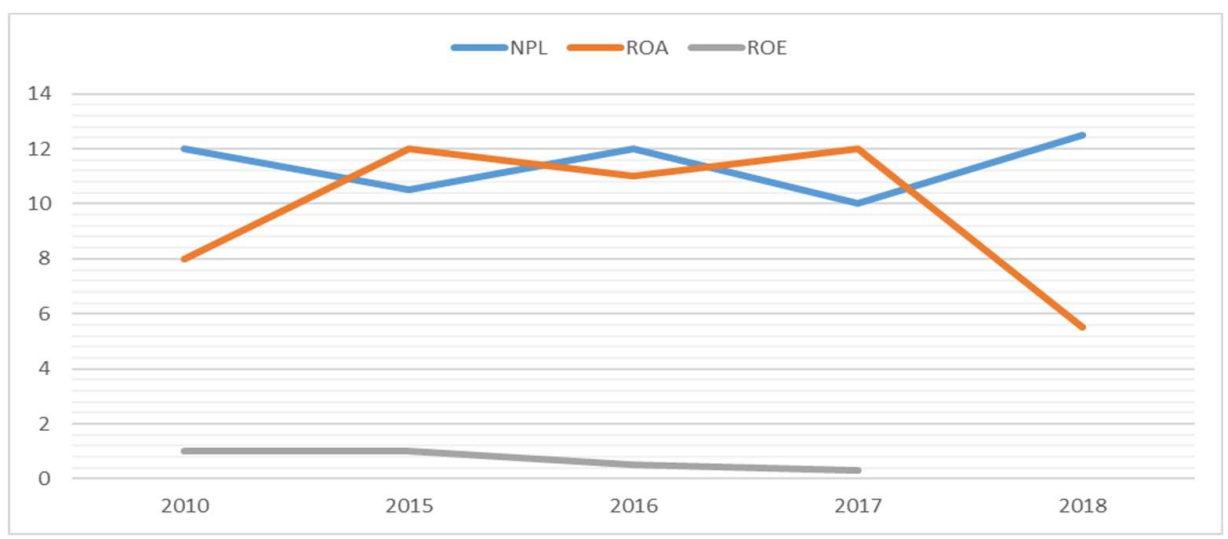

Figure 4. Trends of NPL, ROA, and ROE 
The negative relationship between NPLs and banks' profitability is a major concern for the policymakers. The consequences are depicted as follows:

- Bank needs to keep higher provision as it NPL increases hence it pressure on, banks' profitability.

- Higher NPL would also compel the banks to extending their efforts in recovering the loans from those 'bad' borrowers. In this process, the operational expense (for recovery/ litigation) is assumed to go up.

- $\quad$ Returns on Assets (ROA) and Returns of Equity (ROE) tend to fall down.

- NPLs impair banks' balance sheets and restrict their capacity to lend, hindering investment and growth.

- Vicious cycle: NPL results into economic slowdown as the borrowing firm/individual gradually loses its capability to generate enough earning to pay back the loan. Further injection of money to overcome the crisis is also halted as the borrower is marked as a defaulter in the regulator's record. Eventually, the firm moves into further dire state; and the probability of getting back the money is getting lower for the lending bank.

- Low public confidence: Higher NPL may also lower the public confidence on the bank. In that case, attracting deposit would get even harder which may result the cost of deposit (or borrowing) to increase. Once the cost of fund goes up, the profitability margin tends to shrink.

\section{Evaluating the Measures Adopted to Tackle NPLs}

There is a renowned saying "justice delayed is justice denied". This can be applied to banks in Bangladesh, on account of the presence of degradation and opaqueness in the settlement cycle in addition to weak execution of laws that generally create a productive ground for the headstrong defaulters. In case of Bangladesh, albeit a few laws have been decreed and revised with the end goal of guaranteeing the protection and soundness of the banking system framework, the banking segment still witnesses a distressing amount of NPLs. Therefore, it is significant to measure the real execution of various courts in terms of number of suits documented, pace of settlement and pace of recuperation of NPLs over the years.

The money loan courts (Artha Rin Adalat) were created in 2003 to help swift resolution of disputes between banks and their clients over loan repayment. Currently, a huge backlog of cases, writs by defaulters and the slow execution of the decrees are slowing the loan recovery process.

Table 5. Status of Money Loan Court (Till October 2019)

\begin{tabular}{|c|c|c|}
\hline Total Number of Money Loan Court & Total Pending Cases & Total Tk (billion) \\
\hline 68 & 62,204 & 1176.14 \\
\hline
\end{tabular}

The Bankruptcy Act, 1997, a half-hearted and hasty enactment reveals that the law which once was a sword for the creditor has now become an armor for the debtor. The standing Bankruptcy Act, 1997, a legal background for dealing with NPLs should be reinforced or ratify a bankruptcy and insolvency law, which can be a one-stop solution combining all existing insolvency related laws in attaining liquidation, shielding the interests of small investors, and making the procedure of doing business less cumbersome. It is vital to ensure that the revised Bankruptcy Act sets timebound procedures for Money Loan Courts to expedite the resolution of cases for settlement.

Therefore, the core hindrance relating to the recovery against NPLs are:

- Limitations of the Money Loan Court Act, lack of full-time judges, procrastination of legal actions, etc. In addition, application of 'Bankruptcy Act' is also not relevant.

- Disbursing credit without proper risk analysis, problems in ownership of mortgaged assets, non-existence of the mortgaged assets, lower value of mortgaged assets compared to actual loan, etc. are also responsible for not being able to recover significant amount against NPLs by banks.

Although the banking sector is lumbered with huge amounts of NPLs, it has been reported that the Asian Development Bank recently proposed to finance ministry to lessen NPLs by setting up a public asset management company (PAMC). The establishment of a PAMC to reduce NPLs in Bangladesh, however, poses a few questions. We forget that the fundamental issue of the banking sector in Bangladesh is the lack of governance, and those are of a systemic nature. The first and foremost prerequisite, therefore, is to ensure that there is a strong public commitment to all-encompassing reforms to improve institutions and ensure public transparency. In addition, the government has to inject an initial equity in the operationalization of a PAMC which acts as the company's working capital. Many countries' evidence shows that the Government's initial capital given to an AMC is rarely recovered. This is generally seen as the sunk cost of the government. It is to be seen what, in the case of Bangladesh, the sum of this expense would be. It is necessary to note that the PAMC is not a magic wand to reduce NPLs. A PAMC is expensive to set up and maintain. Such a business can therefore only be formed if the above preconditions are met. Identifying and quantifying risk is extremely important in order to minimize credit risk. Bangladesh Bank (BB) has recently established a new Internal Credit Risk Rating System (ICRRS) method that replaces the previous 
CRG (Credit Risk Grading) scheme. In the present situation, it can be used to stop potential low-quality lending. If ICRRS is applied successfully, businesses with weak debt-intensive financials and low parameters have to boost their scores and it will help to build a healthier lending climate.

\section{Recommendations}

As per the financial system of Bangladesh, the following measures should be adopted to bring the skyrocketing of NPL under control:

- Establishing and operationalizing a specialized Debt Collection Agency efficiently.

- Strictly following the international auditing and accounting standards. Corporate governance should be strengthened and banks must implement proper due diligence in lending decisions.

- Leveraging on predictive analytics to improve credit portfolio quality. This initiative can reduce the portfolio deterioration by $30-40 \%$.

- Regulating the financial control system more sternly. The government and the central bank should ensure that banking rules and regulations are followed rigorously.

- Revamping the existing prudential regulations so that non-performing loans can be kept in a reasonable level. The Bankruptcy Act 1997 and Money Loan Court Act 2003 should be coordinated, so that they complement one another.

- De-linking of trade unions from direct political affiliations.

- Matching of repayment capacity and repayment plans as closely as possible to avoid repayment complications.

- Entrusting the role of supervising the NCBs and the specialized banks to the banking division of the Ministry of Finance. The number of state-owned commercial banks can be reduced through consolidation, merger, or divestment.

- Adopting the centralized decision in case of loan sanctioning.

- Fair pricing of collaterals through competent Accounting Firms. A data warehouse for collaterals also needs to be introduced to avert borrowers from taking loans from several banks by exploiting the same properties as collateral etc.

It is high time steps were taken to ameliorate our financial sector governance for plummeting hazard of bad loans.

\section{Conclusion}

It has been a long time since the adoption of prudential regulations in the banking system of Bangladesh. Regrettably, the banking system is still laden with a frightening amount of NPLs and lags far behind the neighbouring countries like India and Pakistan. Our corporate sector is characterized by high ownership concentration, reluctance of the corporate sector to raise funds through the capital markets, lack of shareholder activism, availability of bank financing and poor enforcement and monitoring of regulations.

However, the main problem in the Bangladeshi banking sector is the presence of default culture. The crux of the problem lies in the accumulation of high percentage of non-performing loans over a long period of time. It has been identified that information problems in the form of moral hazard, adverse selection or monitoring cost of commercial banks in selecting borrowers; the lack of legal actions against defaulters (as a major portion of the loans goes to influential businessmen, politicians and insiders) and the government's practice of debt forgiveness as major reasons for nonpayment of debt in Bangladesh.

Besides, our banking sector is characterized by low profitability and inadequate capital base because there are lots of banks engaged in unhealthy rivalry among themselves. Protection of an ethical standard in the banking industry from other issues can be seen as an essential means of establishing a reliable and vibrant credit environment. The rising trend of the NPL is bound to have a long-lasting negative impact on the country's financial sector. Unless it can be lowered, substantially we will lose competitive edge in the wave of globalization of the banking service that is taking place throughout the world. Resolute measures must be escorted by legal measures, i.e. improving the efficiency of the legal and the judicial system and developing other out of the court settlement measures like compromise settlement schemes, incentive packaging, formation of asset management companies, factoring, and asset securitization and so on.

\section{Competing Interests}

The authors declared no potential conflicts of interest with respect to the research, authorship and/or publication of this article.

\section{Funding}

The authors received no financial support for the research, authorship and/or publication of this article. 
Acknowledgments

Authors would like to thank Associate Professor Mohammed Sohail Mustafa, CFA \& Lecturer Rahat Banu of Bangladesh Institute of Bank Management (BIBM) for their kind guidance and reference in preparing this paper.

\section{References}

Adhikary, B.K. (2006). "Non-Performing loans in the banking sector of Bangladesh: Realities and Challenges", Ritsumeikan Journal of Asia Pacific Studies - RCAPS, Volume 21, pp. 76-95.

Ahmad, M. (1997). “The Political Economy of Loan default: A Quest for a Socio-Political Explanation”. Bank Parikrama, BIBM, Vol. XXX, Issue No. 2.

Azeem, K. (2017), “ $\quad$ Reasons and Effects of Non-Performing Loans in the Banking Industry of Pakistan”, European Journal of Business and Management, Vol.9, No.4, pp. 41-49.

Bangladesh Bank. (2014), "Prudential Regulations for Banks", Available at: https://www.bb.org.bd/aboutus/regulationguideline/prudregjan2014.pdf.

Bangladesh Bank Annual Reprort. (2018-2019), "Chapter 5: Banking Sector Performance, Regulation and Bank Bernanke, B., \& Lown, C. (1991), “The Credit Crunch”, Brookings Papers on Economic Activity 2: pp. 204-248.

Bhattacharyja, D., \& Rashed, M.T. (2000), “Implications of Financial Sector Reform”, CPD occasional paper series 21, pp. 71-89.

Breuer, J. B. (2006), "Problem bank loans, conflicts of interest, and institutions", Journal of Financial Stability, 2, pp. 266-285.

Choudhury, T.A., \& Adhikary, B.K. (2002), "Loan Classification, Provisioning Requirement and Recovery Strategies: A comparative Study on Bangladesh and India", Seminar Paper, Bangladesh Institute of Bank Management, pp. 21-54.

Daily Star (2019), "Sale of non-performing loans to asset management company". Available at: https:/www.thedailystar.net/opinion/macro-mirror/news/sale-non-performing-loans-asset-managementcompany-1833991.

Dey, K.B. (2019), “Managing Nonperforming Loans in Bangladesh”, ADB Briefs No 116, Publication Stock No. BRF190507-2, DOI: http://dx.doi.org/10.22617/BRF190507-2

Godlewski, C.J. (2005), "Bank capital and credit risk taking in emerging economies”, Journal of Banking Regulation, vol 6 (2): pp. 128-145.

Li, Y. (2003), “The Asian financial crisis and nonperforming loans: evidence from commercial bank In Taiwan”, International journal of management, 20(1), pp.69-73

Panta, B. (2019), "Non-Performing Loans and Bank Profitability: Study of Joint Venture Banks in Nepal", International Journal of Sciences: Basic and Applied Research (IJSBAR), Volume 42, No 1, pp 151-165.

Podder, J, and Mamun, A.A. (2004). "Loan Loss Provisioning system in Bangladesh banking: a critical analysis", Managerial Auditing Journal, Vol.19, Issue No.6, pp. 67.

Saba, I., Kouser, R., \& Azeem, M. (2012), "Determinants of non-performing loans: case of US banking sector", The Romanian Economic Journal, 15(44), pp.141-152.

Staikouras, C., \& Wood, G. E. (2004), "The determinants of European Bank profitability", International Journal of Economics and Business Research, 3(6), pp.57-68.

Uddin, M.M. (2019), "Determinants of Loan Default of Low-Income Borrowers in Urban Informal Credit Markets: Evidence from Dhaka City”, European Journal of Business and Management, Vol.11, No.26, pp. 105-114. DOI: 10.7176/EJBM.

Vatansever, M., \& Hepşen, A. (2013), "Determining Impacts on Non-Performing Loan Ratio in Turkey", Journal of Finance and Investment Analysis, 2(4), pp. 119-129. 